\title{
DPIRS Framework for Sustainable Development of Coastal Areas
}

\author{
Rekha S. Nair, Dr. Alka Bharat and Manu G. Nair
}

\begin{abstract}
Presently 21\% of the world population lives within $30 \mathrm{kms}$ of the coastal areas. Coastal zones are therefore of great importance as zones of settlement and play a vital role in the economic well-being of many nations. Indian mainland has a coastline of about $7517 \mathrm{~km}$, with major economic activities and population (due to Migration or otherwise) concentrated in this area. This has resulted in enhanced demand for scarce resources threatening the physical and ecological balance of this entire region. This is mostly due to non-incorporation of inputs from the bottom stakeholders during the planning process and the absence of a holistic treatment in coastal zone management plan preparation. This mismanagement along with the change in climate has resulted in increasing vulnerability, which conspicuously demands a fresh approach towards management of coastal areas.
\end{abstract}

This paper briefly describes the importance of sustainable development of the coastal zone by specifying challenges, the inadequacy of existing measures and suggests a DPSIR framework for improved coastal zone management. Also, a methodology for computing an index has been developed to monitor the sustainability of the region based on Factor analysis.

.Keywords--- Sustainable Development, Coastal Zones, DPSIR, Factor Analysis, Sustainability Index

\section{INTRODUCTION}

$\mathrm{I}_{\mathrm{N} \text { tion }}^{\mathrm{N}}$ $\mathrm{N}$ India 'coastal zone' is defined as 'the area where there is 1 the influence of the high tide.This is of the range of $500 \mathrm{~m}$ from the highest high tide line towards the landward side. The coastal environment plays a vital role in India's economy by virtue of the resources, productive habitats, and rich biodiversity. India's coastline stretches supports almost $30 \%$ of its human population.[1]

In this paper an analysis was done on the sustainable development of coastal zones based on DPIRS (Driver, Pressure, Impact, Response and State) framework. A methodology for sustainable coastal management using DPIRS framework is developed and discussed. Key parameters for monitoring the sustainable development of coastal areasis evolvedusingfactor analysis method,. COASTAL ZONES OF INDIA ECONOMIC IMPORTANCE AND

Rekha S. Nair, Research Scholar, Maulana Azad National Institute of Technology, Bhopal, India. E-mail:srekha11@rediffmail.com

Dr. Alka Bharat, Professor, Maulana Azad National Institute of Technology, Bhopal, India. E-mail:alka.bharat@yahoo.com

Manu G Nair, Sr. Manager, Vodafone India Ltd., Mumbai, India. Email:nairmanug@rediffmail.com

\section{CHALLENGES}

\section{A. Economic and Social Importance of Coastal Zone}

Coastal zone (200m above and $200 \mathrm{~m}$ below sea level as per LOICZ definition) occupies $8 \%$ of the surface of the globe. The coastal zone is the area where around a quarter of global primary productivity occurs. It is here around $60 \%$ of the human population lives, with two thirds of the world cities with population of over 1.6 million people. Coastal zones supplies approximately $90 \%$ of world fish catch [2] The uses of the coastline can be generally be categorized as: resource exploitation (fisheries, gas and oil,); infrastructure (ports, and harbours); tourism and recreation; and the conservation and protection of biodiversity[3].

In India the coastal and offshore environment supports rich biodiversity and provides a basic source of food and income for up to 13 million people. [4]. Thesector's contributions to foreign exchange earnings are substantial with a share of 1.4 per cent of the GDP. Approximately 90\% of the country's trade by volume is moved by the sea (through shipping sector). [5]Tourism with the most prominent being coastal tourism is estimated to have generated 16.6 billion USD in India .[6].Coastal areas has approximately 3, 15,000 ha. of mangrove cover andthose play an important part in the local ecosystem by strongly modulating land-ocean interactions,supporting a diversity of plants, animals and insects crucial to the food chain. [7,8]

\section{B. Challenges in Coastal Zonein India}

\section{i. Violation of Existing Regulations}

For controlled development and sustainability an array of rules and regulations are existing in India. Those worth mentioning are The Coastal Regulation Zone Notification 1991, Indian Ports Act, 1902; Merchant Shipping Act, 1974, Water (Prevention and Control ofPollution) Act, 1974, Indian Coast Guards Act, 1974. [9]

The impacts of these various regulations are not commendable because of its fragmented approach and ineffective implementing mechanisms. This can be exemplified by the various irregularities found in the coastal zone as mentioned in "Mapping the extend of CRZ Violations of the Indian Coast” a report prepared by D. Nandakumar \& M. Muralikrishna[10] for the National Fish workers Forum. Moreover there is no proper monitoring mechanism to measure the implementation and adherence of the policy regulations

\section{ii. Coastal Pollution in Indian Coastal Zone}

Another widespread problem which has not been appropriately addressed is coastal pollution. Most pollution 
incoastal areas of India arises from land-based sources like industrial \&domestic wastes and agricultural run-off. Shipping and associated port activities also play a major role. [2]

These human induced socioeconomic activities lead to a greater impact on the physical and social aspects of the coastal areas. In general the impacts can be classified as Biophysical impacts (flooding, loss of biodiversity etc.) and Socioeconomic impacts (loss of amenity value, impact on aqua culture).[10]

\section{Sustainable Development of CoAstal Zone}

Sustainable development is defined as"development that meets the needs of the present without compromising the ability of future generations to meet their own needs.” This helps in solving the social, economic and environmental issues in the most appropriate manner. Sustainable development cannot happen with the same approach for all the areas. It depends upon the regional, physical, cultural aspects which is inherent of the region [11]. The various stakeholders should be satisfied for their requirements along with the responsibility to maintain and protect the system. Some of the recommendations for sustainable development are

a) Exploit the coastal resources based on its natural characteristics and regional advantages. [12]

b) The eco-system should be protected to ensure sustainable development, act as infrastructure for coastal areas, boost the value of real estate, and provide convenience and services in future. [12]

c) Local authorities and managers should analyse and predict how economic activities impact the ecosystem to properly exploit it. [12]

d) Corporation from all stakeholders are required for sustainable development of the area

e) Awareness among the people about the importance of ecological aspects and nature of the coastal zone.

f) Sustainable development should also consider the assessment of climate change impacts in the coastal area.

A. Sustainable Development in India- Present Response Measures

\section{i. ICZM in India}

On 29th April 2010 Government of India entered into a loan agreement with World Bank for the preparation of Integrated Coastal Zone Management plan. The objectives are to develop and implement an improved strategic plan and integrated management approach for India's coastal zones so

\section{B. Suggestions for an Improved ICZMP}

Various improvement measures have to be done for improving the existing ICZM approach..Some of the Strategies to improve the ICZM project to reduce vulnerability is mentioned in Table 4. as to improve productivity for continued sustainable development and economic growth. The four components in ICZM are:

\section{Component I - Vulnerability and Ecological Mapping}

This component include flood and erosional vulnerability and Ecologically Sensitive Areas mapping and delimitation on the ground of different categories of coastal zones, to be regulated for conservation and for protection against natural hazards.

Component II-National Institution Building and Capacity Strengthening

Establish and operationalize a National Institute for Sustainable Coastal Zone Management, and to develop relevant regulations and institutional setups guiding the linkages between the Centre and the states in order to develop the nationwide approach to coastal zone management(MoEF),

Component III-Development and implementation of statelevel approaches to Integrated Coastal Zone Management

State-level approaches to ICZM would be developed and pilot projects would be implemented in the three selected states of Gujarat, Orissa and West Bengal which will be further extended to whole of India.

\section{Component IV Project Management}

Activities under this component would help to ensure effective project management at national, state and district levels, with information support, communications, monitoring and evaluation.

\section{Current Status of the Project}

The first phase of the project is for a period of 5 years. The project is under implementation in the States of Gujarat, Orissa and West Bengal under the state level State Project Management Units (SPMU).[14]

As the project has started in 2010 and the implementation period is of 5 years ,the completed results are not yet measurable. As per the latest progress reports some slack is now noticed in the Component One at National level .Disbursement performance of funds is observed as low and needs improvement as per the status report submitted to World bank.The draft notification does not recognize that the entire coast is ecologically sensitive. The notification also doesn't specify the monitoring mechanism for implementation of recommendations 
Table 4: Strategies to Improve ICZM for Sustainability

\begin{tabular}{|c|c|}
\hline Strategy & Rationale \\
\hline $\begin{array}{l}\text { Site specific analysis and } \\
\text { contextual development }\end{array}$ & $\begin{array}{l}\text { - Physical and social characteristic varies from region to } \\
\text { region. } \\
\text { - Sustainable development involves the use of resources in the } \\
\text { region in the appropriate manner }\end{array}$ \\
\hline $\begin{array}{l}\text { Re-affirmation of bottom } \\
\text { up approach and } \\
\text { participatory management }\end{array}$ & $\begin{array}{l}\text { - "Institutional structures to support large-scale interventions } \\
\text { are often lacking”[15,16,17] } \\
\text { - "Sustaining large-scale interventions over time will be } \\
\text { exceedingly difficult and costly" }[15,16,17]\end{array}$ \\
\hline $\begin{array}{l}\text { Effective management and } \\
\text { utilization of ICM-derived } \\
\text { outcomes }\end{array}$ & $\begin{array}{l}\text { - "Improvement of economic and environmental conditions } \\
\text { fosters ICM success and sustainability" }[15,17,18] \\
\text { - "Involvement and participation in ICM are influenced by } \\
\text { initial project benefits and perceptions of benefits" } \\
{[15,17,18]}\end{array}$ \\
\hline $\begin{array}{l}\text { Integration in difficult } \\
\text { contexts }\end{array}$ & $\begin{array}{l}\text { - "ICM also depends on integration within and between } \\
\text { multiple governance scales" }[17,19,20,21] \\
\text { - Institutional and legal frameworks that mandate governance } \\
\text { reform are lagging behind the pace of ICM project } \\
\text { evolution" }[17,19,20,21]\end{array}$ \\
\hline $\begin{array}{l}\text { Vertical and horizontal } \\
\text { participatory management }\end{array}$ & 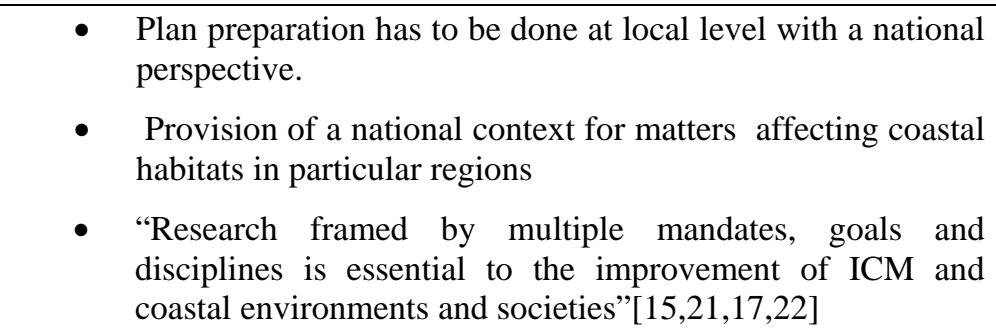 \\
\hline $\begin{array}{l}\text { Long-term commitment is } \\
\text { essential to success and } \\
\text { sustainability }\end{array}$ & $\begin{array}{l}\text { - "Short project time horizons are not conducive to sustained } \\
\text { ICM processes beyond project termination"[17,21] } \\
\text { "Successes of individual ICM efforts can be traced directly } \\
\text { to relatively small groups of committed individuals. } \\
\text { Investment in capacity development in project staff, local } \\
\text { and national agencies, and NGOs are resources well } \\
\text { spent"[17,21] }\end{array}$ \\
\hline $\begin{array}{l}\text { Continuation of the } \\
\text { evaluative and adaptive } \\
\text { process }\end{array}$ & $\begin{array}{l}\text { - "ICM projects investing in data management systems and } \\
\text { engaging local and national government agencies in self- } \\
\text { monitoring exercises" }[15,21,22,17] \\
\text { - "Help track the impacts of ICM efforts; increasingly used to } \\
\text { ensure that ICM project result in tangible and measurable } \\
\text { third-order impacts" }[15,21,22,17]\end{array}$ \\
\hline
\end{tabular}

\section{INTEGRATED COASTAL ZONE MANAGEMENT USING DPISR FRAMEWORK}

The Pressure, State, Response (PSR) framework was initially proposed by Tony Friend and David Rapport for the purpose of analysing the interactions between environmental pressures, state of the environment and environmental responses. The Organization of Economic Co-operation and Development (OECD)has applied Driver, Pressure, State, Impact, Response framework (DPSIR), an adaptation of the PSR frameworkin its environmental reporting [23].
A modifiedversion of OECD framework i.e. DPSIR frameworkhas been used in the present study to construct an integrated framework for sustainable development. In the OECD framework the state of the system will be determined by the Driver and Pressure. The existing rules and regulations and the impact of those regulations is not considered in determining the state of the system.

Here in thismethodology (Fig 1) the present initiatives already done by many coastal countries for the sustainable development of the coastal areas are taken into account. This 
methodologydefines that the driver is exerting pressure on the local ecosystem which causes various impacts. The existing regulations (Response mechanisms) intervene to reduce the impact (mitigating, reversing or adapting as per conditions) caused by the driver by means of the various policies. The response will have some indirect reaction as well asa direct reactionto the impact. The state of the system after the response is the cause of concern presently and has to be measured and continuously evaluated and anadaptive process has to be developed in order to fulfil the varying requirements of the future. A further elaboration of the proposed methodology is given below (Section 4)

\section{Proposed Methodology for Preparing InTEgrated CoAstal Zone MANAgEMENT PlAn BY USING DPIRS FRAMEWORK AND MONITORING THE IMPLEMENTATION AND CONTINUOUS ASSESSMENT THROUGH INDICATOR APPROACH}

(FIG.1)

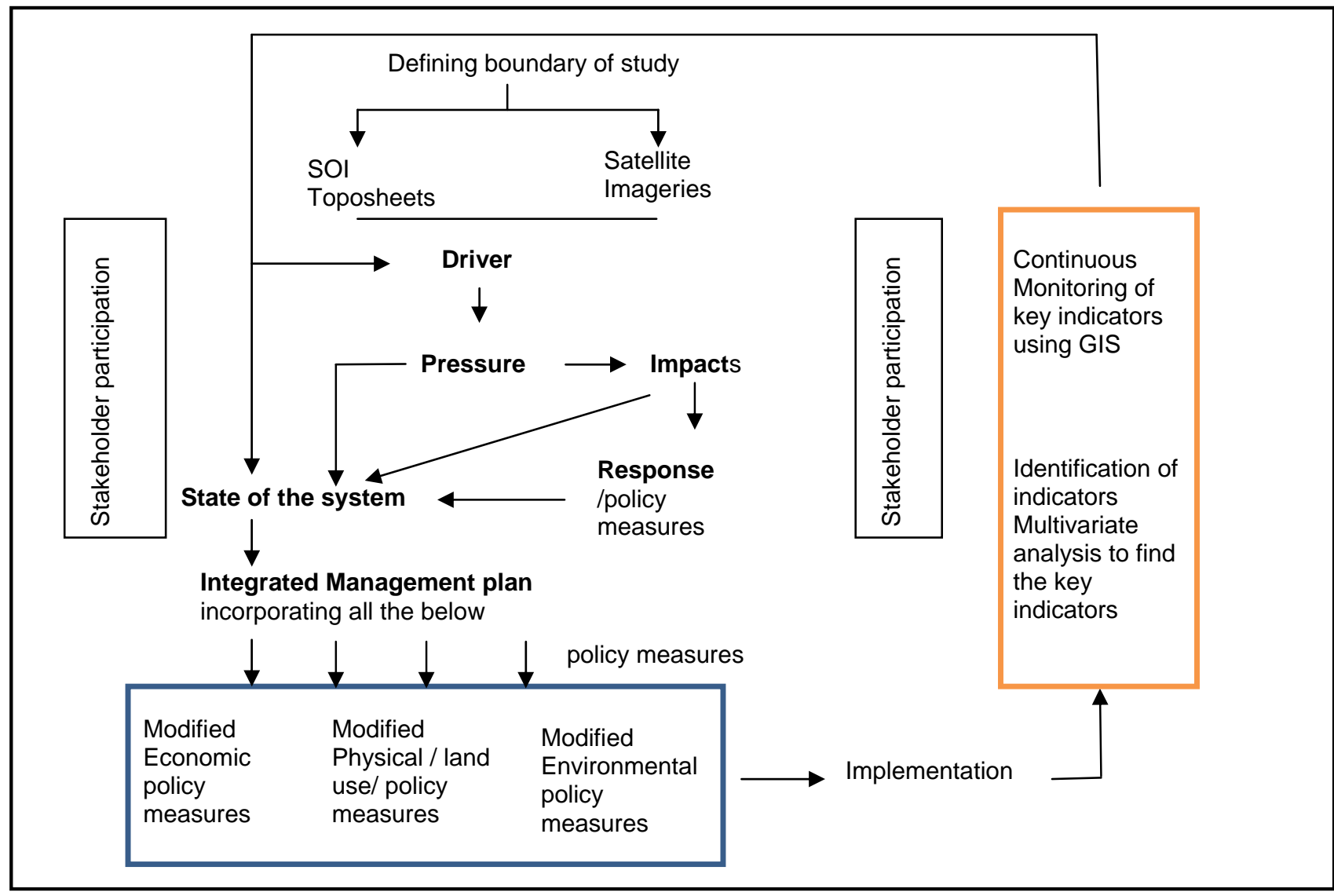

The three main components of this model are- Driving force, Pressures, Impacts, Responsewhich determine the states of the system, the integrated management plan prepared on the basis of DPIRS framework, and the continuous monitoring of the execution of the plan.

A bottom up approach has to be taken preparation of integrated coastal zone management plan. The local unit has to be identified and study area to be delineated with the help of GIS ,validated with topo-sheet data. The driving forces, the pressure exerted by them, the different response measures already in place and their impacts have to be identified. The existing state of the system has to be analyzed along with stakeholder participation. Long term Economic and social improvement should also be given due consideration while formulating policy measures. The overall policy measures should help in solving social, economic and environmental issues with co-operation and benefits of the stakeholders. Educating and capacity building of the stakeholders of the long term benefits of sustainable planning will help in obtaining proper co-operation.

The various terminologies as mentioned in the above methodology is detailed down

Driver

A force which causes a physical or socio-economic need for e.g. urbanization which causes need for land

\section{Pressures}

Driving forces lead to human activities which will result in meeting a need. These human activities exert 'pressures' on the environment, as a result of production or consumption processes, which can be divided into three main types: (i) excessive use of environmental resources, (ii) changes in land use, and (iii) emissions (of chemicals, waste, radiation, noise) to air, water and soil. [24] 


\section{Impacts}

The changes in the physical, chemical or biological state of the environment determine the quality of ecosystems and the welfare of human beings. In other words changes in the state may have environmental or economic 'impacts' on the functioning of ecosystems, their life supporting abilities, and ultimately on human health and on the economic and social performance of society. [24]

\section{Responses}

A 'response' by government or the stakeholderstake as a result of an undesired impact and can affect any part of the chain between driving forces and impacts. An example of a response related to driving forces is prevention of migration, or against pressure is land use zoning.

\section{States}

The state which is mentioned here is the 'state' of the system , that is, the quality of the various environmental factors (biotic and abiotic.) in relation to their functions. This state is as a result of various interactions as well as the existing response measures adopted by the various agencies.

- Existing Land condition

- Air quality

-Water quality (river, lake, sea, and groundwater

Table 5. Relation between Driver,Pressure and Impact in Coastal Areas of India

\begin{tabular}{|c|c|c|}
\hline Driver & Pressure & Impact \\
\hline $\begin{array}{l}\text { Urbanization } \\
\text { Unplanned development, Weak } \\
\text { framework of regulations }\end{array}$ & $\begin{array}{l}\text { Population growth leading to pressure } \\
\text { for land, poor development policies }\end{array}$ & $\begin{array}{l}\text { Coastal development and reclamation } \\
\text { Development of infrastructure along the } \\
\text { coast } \\
\text { Conversion and other habitat loss }\end{array}$ \\
\hline $\begin{array}{l}\text { Industrial demand } \\
\text { Increasing demand with depleting } \\
\text { resources }\end{array}$ & $\begin{array}{l}\text { Pollution from untreated or } \\
\text { insufficiently treated waste materials }\end{array}$ & $\begin{array}{l}\text { Massive destruction of biotic organism } \\
\text { Change in quality of water }\end{array}$ \\
\hline Demand for food production & $\begin{array}{l}\text { Agricultural effluents loaded with } \\
\text { nitrogen } \\
\text { Nutrient loading }\end{array}$ & $\begin{array}{l}\text { Coastal waters suffering from } \\
\text { eutrophication } \\
\text { Change and loss of biodiversity, }\end{array}$ \\
\hline Need for Economic development & $\begin{array}{l}\text { Shift to market economies, demand } \\
\text { for live food fish, increasing } \\
\text { competition in light of diminishing } \\
\text { resources } \\
\text { Increased need of aquaculture areas } \\
\text { Destructive fisheries }\end{array}$ & $\begin{array}{l}\text { Loss of coastal ecosystem } \\
\text { Loss of coastal wetlands }\end{array}$ \\
\hline $\begin{array}{l}\text { Recreation demand and Coastal } \\
\text { Tourism }\end{array}$ & $\begin{array}{l}\text { Lack of } \text { alternative materials, poor } \\
\text { national } \quad \text { policies } \\
\begin{array}{l}\text { competition, lincreased } \\
\text { deforestation }\end{array}\end{array}$ & Habitat loss, Degraded water quality \\
\hline Need of building material & $\begin{array}{l}\text { Lack of alternative materials, which } \\
\text { causes sand mining dredging }\end{array}$ & Habitat loss, Degraded water quality \\
\hline Demand for infrastructure & $\begin{array}{l}\text { Transport and energy demands, poor } \\
\text { public policy, which requires Port } \\
\text { Civil engineering works }\end{array}$ & Habitat loss or conversion \\
\hline $\begin{array}{l}\text { Demand for luxury items and food } \\
\text { items }\end{array}$ & $\begin{array}{ll}\begin{array}{l}\text { Aquaculture-related } \\
\text { conversion }\end{array} & \text { habitat } \\
\end{array}$ & Habitat loss or conversion \\
\hline Lack of knowledge & $\begin{array}{l}\text { Pollution: toxins and pathogens from } \\
\text { land-based sources }\end{array}$ & $\begin{array}{l}\text { Coastal degradation } \text { Degraded air } \\
\text { quality }\end{array}$ \\
\hline $\begin{array}{l}\text { Lack of emission control of } \\
\text { greenhouse gases }\end{array}$ & $\begin{array}{l}\text { Global warming and sea-level rise } \\
\text { Environmental refugees and internal } \\
\text { migration }\end{array}$ & $\begin{array}{l}\text { Socio - Economic loss } \\
\text { Salt water infiltration } \\
\text { Inundation and loss of land } \\
\begin{array}{l}\text { Destruction of ecologically sensitive } \\
\text { areas }\end{array}\end{array}$ \\
\hline
\end{tabular}




\section{Monitoring Mechanism}

As mentioned earlier formulating a plan and adopting it doesn't end the process of Integrated Coastal Zone Management. It requires continuous adaptive evaluation. Effective, continuous monitoring of the physical state of the system can be done by means of a Geographical Information System which will not require much of resource and manpower.

The monitoring mechanism should consider the biophysical and socioeconomic environment of the coastal area into consideration. This can be simultaneouslymeasured by means of an indicator based sustainability index. This will also help in comparative analysis and prioritizing initiatives.Understanding and comparing sustainability across the region can best be done using sustainability index developed using factor analysis.

\section{Selection of Indicator}

Considering the general characteristic of the coastal zone of India and from the various literature reviews a set of Indicators was derived for Indian coastal areas.

The 25 indicators which were found apt are

1. Land use change

2. Human and economic loss due to natural disasters

3. Quality of water

4. Protected areas

5. Mangrove cover

6. Proportion of coastal areas protected

7. Tourism revenue in GDP

8. Employment in the tourist sector

9. Fish catches and economy

10. Industrial growth

11. Ratio resident/non-resident tourism

12. Change in employment in the sectors of aquaculture and agriculture

13. Ratio of business started/bankrupt

14. Housing quality

15. Water quality

16. Domestic waste

17. Generation of hazardous waste by industries

18. Traffic pressure on the road

19. Economic value of the shipping industry versus emission of toxic dust

20. Number of good renovations and restorations

21. \% of population under coastal areas

22. Land using agricultural pesticides
23. Erosion/Accretion of coastal areas

24. \% of Land under Mining

25. Land reclamation

These 25 indicators were clustered into 4 factors using factor analysis. Factor analysis is used to simplify themultivariate dataset (indicators)in order to understand the trends and associations more clearly. Factor analysisclusters variables in similar terms, generating fewer variables (called components or factors) thatexplain a large percentage of the variability of the original variables. Factor analysis also removes multi-collinearitybetween variables and combines those that are highly correlated (positively or negatively) toreduce redundancy in the variables.For the factor analysis , Factor model (Release 8.1, April, 2012) developed by Rovira i Virgili University, Tarragona, SPAIN was used.

In this analysis the appropriateness of the data for factor analysis was tested through Kaiser-Meyer-Olkin (KMO) test . using Factor model (Release 8.1, April, 2012) developed by Rovira i Virgili University, Tarragona, SPAIN

The KMO test comparedthe magnitude of the observed correlation coefficients to the magnitude of the partial correlation coefficients. [25,26,27]

The Kaiser-Meyer-Olkin criterion is calculated as

$$
K M O=\frac{\sum_{j \neq k} \sum_{j r^{2}}}{\sum_{j \neq k} \sum r_{j k}^{2}+\sum_{j \neq k} \sum p_{j k}^{2}}
$$

Here is $r_{j k}$ the correlation between two variables, and $p_{j k}$ the partial correlation [25]

This testyielded a result of 0.80033 showingthe appropriateness of the data for factor analysis.

The number of factors which has to be considered was determined based upon the Eigenvalue.As per the factor model output four factors were found to have Eigen values greater than 1. Also, these number of factors (four) was re-confirmed by using Cattell scree plot(Fig. 2)as given below.The Cattell scree test plots the components as the $\mathrm{X}$ axis and the corresponding eigenvalues as the $\mathrm{Y}$-axis.As one moves to the right, toward later components, the eigenvalues drop. When the drop ceases and the curve makes an elbow toward less steep decline, Cattell's scree test says to keep the number of factors above the "elbow" in the plot. 


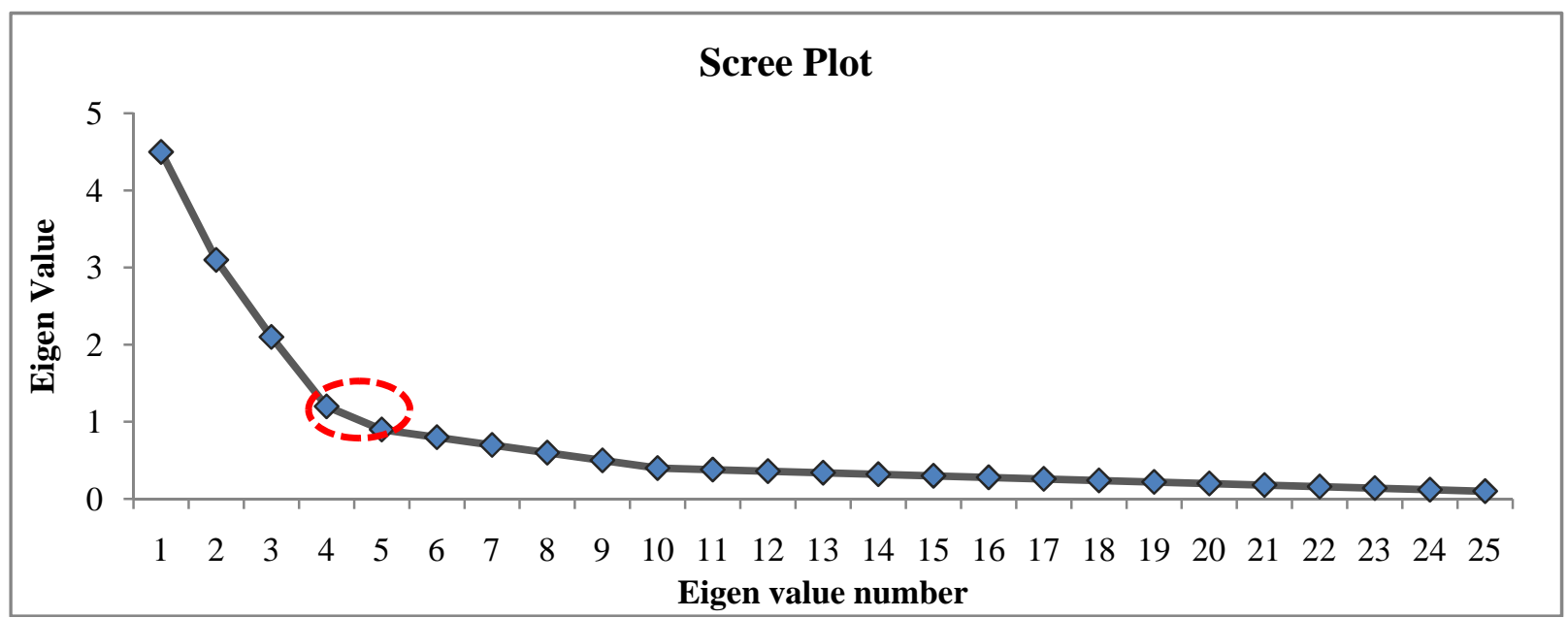

Figure 2: Scree Plot

Varimax rotation method (in Principal component analysis)was used to filter and categorize the indicators into four factors based on rotated correlation matrix.(Output of Factor analysis model) Here out of 25 indicators, 12 indicators were found to be highly correlated and hence are critical in determining the sustainability of the area as shown in Table 6.

Table 6. Selection of factors and indicators

\begin{tabular}{|c|l|c|l|}
\hline Factor & Factor name & $\begin{array}{c}\text { \% variance } \\
\text { explained }\end{array}$ & Highest correlated indicators \\
\hline 1 & Resources & $28.3 \%$ & $\begin{array}{l}\text { \% of population under coastal areas (89.18\%), Tourism revenue in GDP(86.93\%), Housing } \\
\text { Quality (82.45\%), Water quality(77.01\%), Ratio of business started/bankrupt (-71.29\%) }\end{array}$ \\
\hline 2 & Industry & $24.1 \%$ & Industrial growth( 85.22\%), Generation of hazardous waste by industries(82.78\%) \\
\hline 3 & Land use & $18.7 \%$ & $\begin{array}{l}\text { Land using agriculture pesticides( 85.22\%),\% of land under mining activity (79.37\%), land } \\
\text { reclamation (78.34\%), mangrove cover (-83.11\%) }\end{array}$ \\
\hline 4 & Employment & $8.3 \%$ & Employment in tourist sector( 91.38\%) \\
\hline & Total & $79.4 \%$ & \\
\hline
\end{tabular}

After deriving the factors and its constituent variables which determine the sustainability a sustainability index has been formulated

Sustainability index $=$ Resources $(5$ indicators) + Industry (2 indicators) +Landuse (4 indicators) +Employment (1 indicator)

Benchmarking of sustainability index can be done based on the requirement of the area and appropriate actions can be done when the value goes below the specific benchmark.

\section{CONCLUSION}

With a coastal line of $7150 \mathrm{~km}$ and a population density of 450 people per square feet, the impact of human induced factors makes the coastal areas of India highly vulnerable. The human, socio and economic catastrophe caused by cyclone in Kandla in 1998, Orissa in 1999 and Tsunami in 2004 clearly elucidated the deficiencies in the current coastal planning and management approach. The pollution and the violations of the regulations exults the inadequacy of the existing approach. The current approach has led to various initiatives which do not lead to a sustainable development of the coastal areas since the vulnerability at local level is not properly addressed and continuous monitoring mechanisms have not been implemented, which conspicuously demands a fresh approach towards management of coastal areas

In this study a new methodology for Integrated Coastal Zone Management is proposed using DPIRSframework , taking into account the proper coordination from all authorities and stake holders. This will help further to promote sustainable development by taking into account environmental, social and economic factors. A four factor i.e. 12 indicator based monitoring mechanism (sustainability index) is proposed along with the frame work which will help in developinga long term evaluative and adaptive monitoring process.

\section{REFERENCES}

[1] CRZ Notifications GOI., 6th January, 2011 http://www.moef.nic.in/downloads/public-information/CRZNotification2011.pdf Accessed on 27/04/2012

[2] Elrich de Sa, NIOANNUAL REPORT 2003-2004 www.nio.org/userfiles/file/annual_report/2003-04.pdf Accessed on $26 / 04 / 2012$ 
[3] Kay and Alder, 2005, Coastal planning \& Management, Taylor \& Francis, 2005

[4] NIO SAARC Workshop http://saarcsdmc.nic.in/pdf/workshops/goa/india/COASTAL\%20AND\%20MARIN E\%20POLLUTION.pdf

[5] Ports of India http://www.indiaonestop.com/ports.htm Accessed on 3/05/2012

[6] India Tourism Statistics at a Glance" Ministry of Tourism, Government of India.

http://tourism.gov.in/writereaddata/CMSPagePicture/file/marketresearch /INDIATOURISMSTATICS\%28ENGLISH\%29.pdf Accessed on 26/04/2012

[7] H.J. Rutinbeek, Mangrove Management: An Economic Analysis of Management, EMDI Environmental Reports, Dalhaousie University 8,1992

[8] Elrich de Sa NIO, Present state of the coastal environment in India http://www.teriin.org/teri-wr/coastin/papers/paper2.htm Accessed on 26/04/201

[9] M S Swaminathan, M S Swaminathan Report of the committee chaired by M S. Swaminathan to review the Coastal Regulation Zone Notification 1991 http://moef.nic.in/mef/crz_report.pdf . Accessed on 20/03/2012

[10] D N. Kumar, Muralikrishna, Mapping the Vulnerability of Indian Coastal Areas, Report for National Fishworkers Forum, Valiathura, Thiruvananthapuram,1998,

http://www.ceeindia.org/cee/pdf_files/cmz_violation_studyby_thomas_k ocherry.pdf Accessed on 20/03/2012

[11] Nursey-Bray, Melissa, and Robert Palmer. "Coastal Zone." Encyclopedia of Environment and Society. Ed. Paul Robbins. Thousand Oaks, CA: SAGE Publications, Inc., 2007. 292-93. 2012.

[12] Dr Nguyen Chu Hoi , Overexploitation of coastal areas contributes to climate change, Ministry of Natural Resources and Environment Vietnam ,Vietnam news,2012 Accessed on 26/05/2012 http://talkvietnam.com/2012/04/overexploitation-of-coastal-areascontributes-to-cc/\#.UJi9Q4YY3Mg

[13] ICZM, India, Gujarat Government (World Bank Aided) http://gec.gov.in/iczmp.html Accessed on 02/05/2012

[14] ICZM, India , Status report, Implementation status and results ICZM IndiaPD97985,

http://documents.worldbank.org/curated/en/2012/01/15638981/indiaintegrated-coastal-zone-management-p097985-implementation-statusresults-report-sequence-0 Accessed on 02/05/2012

[15] Pollnac, R.B. \& R. Pomeroy. 2005. Factors influencing the sustainability of integrated coastal management projects in the Philippines and Indonesia. Ocean and Coastal Management.

[16] Oracion, E.G., Miller, M.L. \& P. Christie. 2005. Marine protected area for whom? Fisheries, tourism, and solidarity in a Philippine community. Ocean and Coastal Management.

[17] Kay, FAO, Workshop on Coastal Area Planning and Management in tsunami affected countries: Bangkok, September 27th-29th, 2006,Integrated Coastal zone Planning in Asian Tsunami Affected Countrieshttp://www.fao.org/forestry/13090 0dbad2d207e029dbfa3e34c51316d7aa9.pdf , Accessed on 15/03/2012

[18] Pomeroy, R.S., Oracion, E.G., Pollnac. R.B. \& D.A. Caballes. Undated. Perceived economic factors influencing the sustainability of integrated coastal management projects in the Philippines. Ocean and CoastalManagement

[19] Eisma, R.V., Christie, P. \& M.J. Hershman. 2005. Legal issuesaffecting sustainability of ICM in the Philippines. Ocean and Coastal Management.

[20] Patlis, J.M. Undated. The role of law and legal institutions in determining thesustainability of integrated coastal management projects in Indonesia. Ocean and Coastal Management.

[21] White, A.T., Christie, P., Agnes, H.D., Lowry, K. \& N. Milne. 2005. Designing ICM projects for sustainability: lessons from the Philippines and Indonesia. Ocean and Coastal Management 48

[22] Olsen, S.B. \& P. Christie. 2000. What are we learning from tropical coastal management experiences? Coastal Management, 28: 5-18.

[23] OECD, Using the pressure-state-response model to develop indicators of the sustainability OECD framework for environmental indicators www.ibama.gov.br/category/59?download=2919Accessed $21 / 05 / 2012$

[24] Peter Kristensen The DPSIR Framework Paper,Presented at the 27-29 September 2004 workshop on a comprehensive / detailedassessment of the vulnerability of water resources to environmental change in Africa using river basin approach. UNEP Headquarters, Nairobi, Kenya http://enviro.lclark.edu:8002/rid=1145949501662_742777852_522/DPS IR\%20Overview.pdf Accessed on 14/05/2012

[25] http://de.wikipedia.org/wiki/Kaiser-Meyer-Olkin-Kriterium

[26] W. Ludwig-Mayerhofer: factor analysis.ILMES - Internet Encyclopedia of Methods of Social Research, 5th Accessed June 2004, on 30 January 2011.

[27] EE Cureton, / D'Agostino, RB 1983: Factor analysis: an applied approach. Hillside, NJ: Lawrence Erlbaum Associates, pp. 389 f

[28] D. StanwellSmith, International Biodiversity Indicator Frameworks and Reporting ,UNEP World Conservation Monitoring Centre , 2010 http://www.bipnational.net/LinkClick.aspx?fileticket=WyXd5eVSbrg\% 3D\&tabid $=120 \&$ language $=$ enAccessed on 15/04/2012

[29] J E.Cohen, et al., "Estimates of coastal populations", Science 278: Pp1211-1212, 1997

[30] R.Gommes,. et al. "Potential impacts of sea level rise on populations and agriculture”, Food and Agriculture Organization of the United Nations, SD (Sustainable Development Department) 1998http://www.fao.org/sd/EIdirect/EIre0046.htm Accessed on 05/05/2012

[31] J.R.Clark, Coastal zone management handbook. Taylor \& Francis1995

[32] M C Pathak, RanjaySinha, R Nigam, A R Gujar and K L Kotnala; Concepts, Approaches and applications of Integrated Coastal Zone Management in Planning and Management of Indian Coast,Proceeding Volume, National Seminar, Four decades of marine geosciences in India. A Retrospect, GSI, MW, Mangalore Pp 202-205,2001

[33] Christian Heidorn , Towards Streamlining of Environmental Indicators, Indicator Clearing House, 2010 http://unstats.un.org/unsd/environment/fdes/EGM1/EGM-FDES.1.22Streamlining\%20Environmental\%20Indicators\%20\%20Christian\%20Heidorn_ppt.pdf

[34] R. K. Turner, W N Adger Coastal Zone Resources Assessment Guidelines, LOICZ Reports and Studies, Number 4, 1995 http://www.loicz.org/imperia/md/content/loicz/print/rsreports/4_coastal_ zone_resources.pdf Accessed on 26/04/2012

[35] M. Hannelore, Kathy Belpaeme, Ann-Katrien Lescrauwaet and Jan Mees, Indicators as guides for Integrated Coastal Zone Management 2006

http://www.safecoast.nl/editor/databank/File/Belgian\%20indicators\%20f or\%20iczm.pdf Accessed on 15/04/2012 